\title{
rRNA gene activity and control of expression mediated by methylation and imprinting during embryo development in wheat $x$ rye hybrids
}

Received: 10 October 1994/ Accepted: 5 January 1995

\begin{abstract}
Ribosomal RNA genes originating from one parent are often suppressed in interspecific hybrids. We show that treatments during germination with the cytosine analogue 5-azacytidine stably reactivate the expression of the suppressed rRNA genes of rye origin in the wheat $\times$ rye amphiploid, triticale, by preventing methylation of sites in the rye rDNA. When 5-azacytidine is applied to embryos of triticale and wheat $x$ rye $F_{1}$ hybrids nine, or more, days after fertilization, rye rRNA gene expression is stably reactivated in the resulting seedling. Earlier treatments have no effect on rye rRNA gene expression, indicating that undermethylation of DNA early in embryo development is reversible. After 9 days, the methylation status of rRNA genes in maintained throughout development. Since the change in expression follows a methylation change at particular restriction-enzyme sites, the data establish a clear correlation between gene activity and methylation in plants.
\end{abstract}

Key words Nucleolar dominance - Genomic imprinting - NOR expression · Silver staining

\section{Introduction}

Nucleolar dominance, where the rRNA genes from one parent are suppressed, is well known in plant and animal interspecific hybrids (Navashin 1934; Reeder 1985). Lacadena et al. (1988) have summarized the hierarchy of supression of rRNA genes in many hybrids between species in the tribe Triticeae. In wheat $\times$ rye $F_{1}$ hybrids

Communicated by G. S. Kush

N. Neves $(\bowtie)$ - J. S. Heslop-Harrison

Karyobiology Group, Department of Cell Biology, John Innes Centre, Norwich NR4 7UH, UK

W. Viegas

Departamento de Botânica, Instituto Superior de Agronomia, P1399, Lisboa, Portugal (either ABR or ABDR genome constitution), and in the amphiploid triticale (AABBRR), the rRNA genes of rye origin are strongly suppressed (Lacadena et al. 1984).

The rDNA occurs as a tandemly repeated unit, with the genes encoding the $18 \mathrm{~s}, 5.8 \mathrm{~s}$ and $25 \mathrm{~s}$ rRNA at the nucleolar organizing regions (NORs). Several results have indicated the involvement of methylation in gene expression (Heslop-Harrison 1990; Vieira et al. 1990; Ottaviani et al. 1993) and in wheat rRNA gene expression partly depends on the structure of the large intergenic region between the $25 \mathrm{~s}$ and $18 \mathrm{~s}$ genes in the rDNA repeat unit (Sardana et al. 1993). The cytosine analogue 5-azacytidine (5-AC) inhibits many proteins binding to DNA (Hayashibara and Verdine 1992) and acts as a false substrate and potent inhibitor of DNA methyltransferases (methylases; Jones 1985). Hence 5-AC incorporation, even at low levels, causes newly replicated DNA to be under-methylated. It has been shown that rRNA gene expression can be evaluated by silver staining of the acidic non-histonic proteins in the nucleoli, which remain associated with metaphase chromosomes at the NORs active at the previous interphase (Hubbell 1985; Jimenez et al. 1988).

In wheat $\times$ rye $F_{1}$ hybrids, inactivation of the rye rDNA must occur during embryogenesis, as in the case of animals where developmental patterning occurs at this stage (Ferguson-Smith et al. 1993). Thus we aimed to investigate the effect of 5-AC on rRNA gene imprinting during embryo development in wheat $\times$ rye $F_{1}$ hybrids and in triticale. We also examined the correlation between methylation and rRNA gene expression patterns in triticale to study the control of this imprinting system.

\section{Materials and methods}

Hexaploid wheat (Triticum aestivum $\mathrm{L}$. em Thell cv Chinese Spring, $2 n=6 x=42$, genome constitution AABBDD) $\times$ rye (Secale cereale $\mathrm{L} ., 2 \mathrm{n}=2 \mathrm{x}=14, \mathrm{cv}$ Centeio do Alto, $\mathrm{RR}$ ) $\mathrm{F}_{1}$ hybrids were obtained by sexual hybridization, and have 28 chromosomes (ABDR). Triticale ( $x$ Triticosecale Witt., $2 \mathrm{n}=6 \mathrm{x}=42$, AABBRR) is a fertile amphidip- 
loid derived by doubling the chromosome number of the $F_{1}$ hybrid between durum wheat ( $T$. turgidum $\mathrm{L}$., $2 \mathrm{n}=4 \mathrm{x}=28$, AABB) and rye; the varieties Lasko (Poznan Plant Breeders, Poland), Juanilho and Drira (ENMP, Elvas) were used in our experiments.

For examination of the effects of 5-AC during embryogenesis, hexaploid wheat and triticale were emasculated and pollinated artifcially with rye and triticale pollen respectively. The volume enclosing the developing embryos was injected with $100 \mu \mathrm{l}$ of a $10 \mu \mathrm{g} / \mathrm{ml} 5-\mathrm{AC}$ solution on three consecutive days, centred 3,6 and 9 days after pollination in the three different treatments. The seed was then matured normally, germinated in water, and the roots were silver stained. Seeds were germinated at $24^{\circ} \mathrm{C}$ in the dark for about 3 days and metaphases accumulated in $1.25 \mathrm{mM}$ hydroxyurea over $18 \mathrm{~h}$. Root-tips were fixed in formaldehyde (37\%):acetic acid: $50 \%$ ethanol $(1: 1: 18)$ at $4^{\circ} \mathrm{C}$ for $2-3$ days. After washing, they were soaked in a $15 \%$ silver nitrate solution, pH 5.5 , at $60^{\circ} \mathrm{C}$ for $16 \mathrm{~h}$ in the dark before washing, then developed in 10\% formaldehyde (37\%): 1\% hydroquinone (1:1), $5 \mathrm{~min}$, and fixed in $4 \%$ Kodafix. Washed root-tips were dissected and squashed in $45 \%$ acetic acid.

To examine the effects of 5-AC on germinating embryos, dry seeds were imbibed and germinated in water or in a $10 \mu \mathrm{g} / \mathrm{ml}$ solution of 5-AC, in a Petri dish on filter paper in the dark, which was renewed daily. One or two root tips per seed were excised and silver stained as above, while the seedlings were grown for DNA extraction.

DNA isolation, enzyme digestion, Southern transfer and nonradioactive hybridization (Amersham ECL) were carried out with standard methods (Anamthawat-Jónsson et al. 1990) using as probes the wheat rDNA repeat unit clone, pTa71 (Gerlach and Bedbrook 1979), and the rye intergenic spacer clone, pScR4.T1 (Appels et al. 1986), kindly supplied by R.B. Flavell and R. Appels respectively.

\section{Results}

Figure 1a shows an untreated root-tip metaphase from triticale having two pairs of chromosomes with active rRNA genes on sub-terminal NORs, identified as the major wheat NOR chromosomes $1 \mathrm{~B}$ and $6 \mathrm{~B}$. More than $92 \%$ of untreated cells showed three or four silverstained satellite NORs. After 5-AC treatment, more than $90 \%$ of cells showed three pairs of subterminal NOR chromosomes with active rRNA genes; the pairs are $1 \mathrm{~B}$ and $6 \mathrm{~B}$ from wheat and the only NOR chromo- some from rye, 1R (Fig. 1b). These three chromosome pairs are the only ones with satellite NORs.

Southern-blot hybridization analysis using rDNA cloned from wheat as a probe to DNA from control and 5-AC-treated triticale plants showed that an extra restriction fragment was present only in DNA from the treated plants digested with $A p a I$, a methylation-sensitive restriction enzyme (Fig. 2a). The same blot, reprobed with a clone of the rye rDNA inter-18s-25sspacer, showed that the extra fragment, now showing a strong hybridization signal, originated from the rye intergenic spacer region (Fig. 2b).

Counts of silver-stained NORs in metaphases from Triticale seedlings from embryos injected with 5-AC shortly after fertilization showed that those from treatment 9 (injected 8, 9 and 10 days after pollination) regularly had five or six active NORs, in contrast to the control and treatments 3 and 6, where most cells showed only four major NORs (Table 1). In $F_{1}$ hyrids, no cells with more than two subterminal NORs were found from the control and treatment 3 , while $80 \%$ of treatment 9 cells had three subterminal NORs (Table 1, Fig. 3).

\section{Discussion}

The control of gene expression by methylation has been widely discussed, but there are few cases where modification of methylation has been shown to alter expression (Barlow 1993). This is at least partly because of the difficulty of examining the activity of any specific gene locus. As well as being of practical importance in crops, the wheat-rye rDNA system is an ideal model because expression of individual loci can be monitored and, as shown here, may be modulated and controlled at a specific developmental stage in the life of the plant.
Fig. 1a, b Triticale metaphases after silver staining showing rRNA gene activity at the previous interphase. a Root-tip metaphase from an untreated seedling with two pairs of chromosomes with silver-stained subterminal NORs (arrows), both of wheat origin. b Root-tip metaphase from a seed germinated in 5-AC with three paris of silver-stained, active NORs (arrows). The major silver signal detected at six intercalary sites shows the expression of NORs on the three pairs of satellited chromosomes (the two major wheat-origin NORs and the pair of rye-origin NORs). As often seen, there is some staining of heterochromatin of rye origin
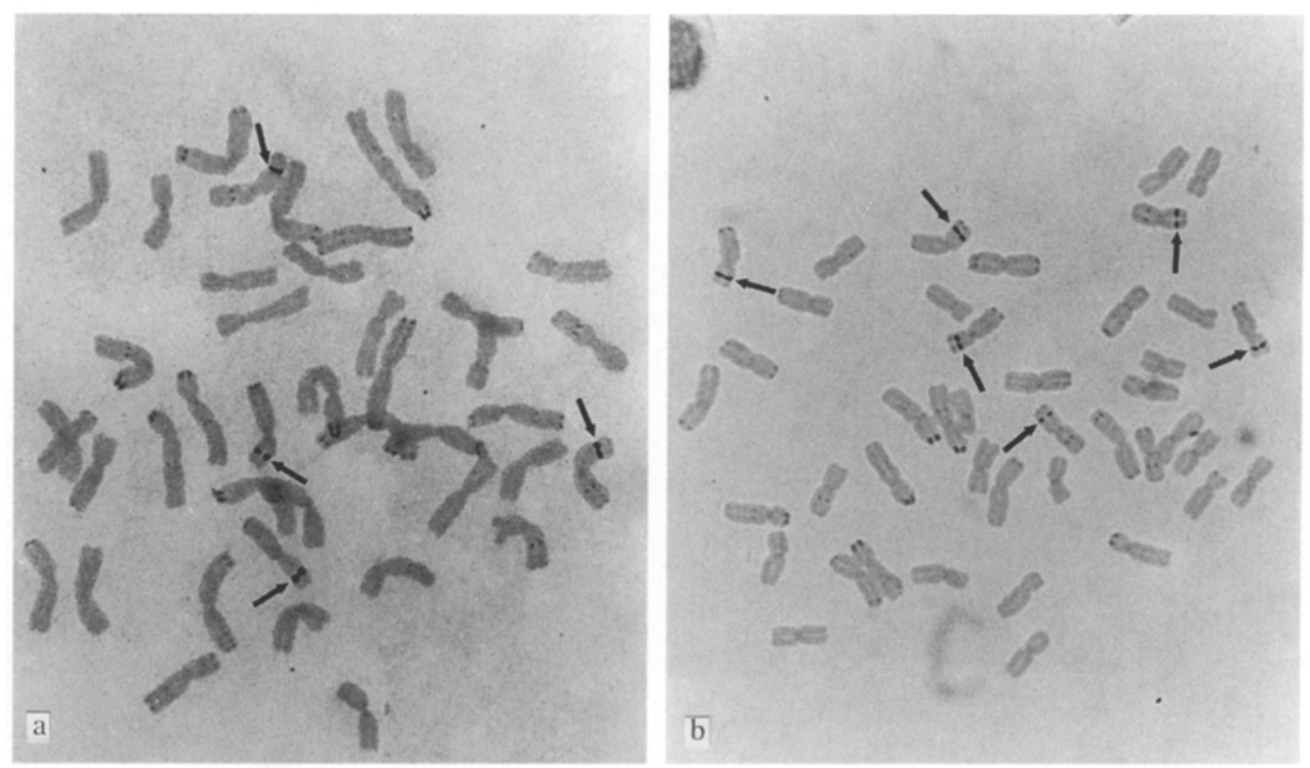
a

$\begin{array}{lllllll}M & 1 & 2 & 3 & 4 & 5 & 6\end{array}$

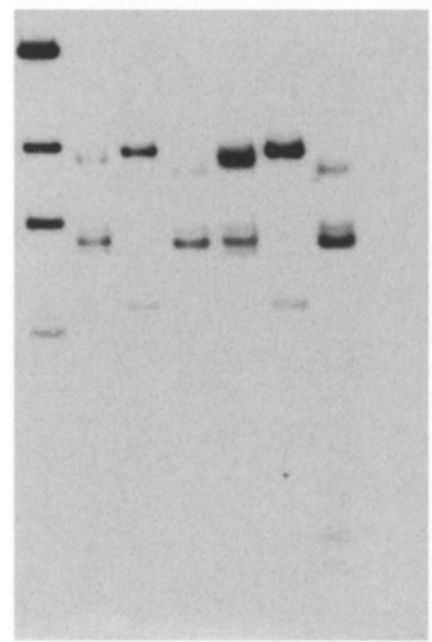

b

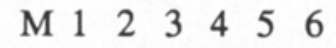

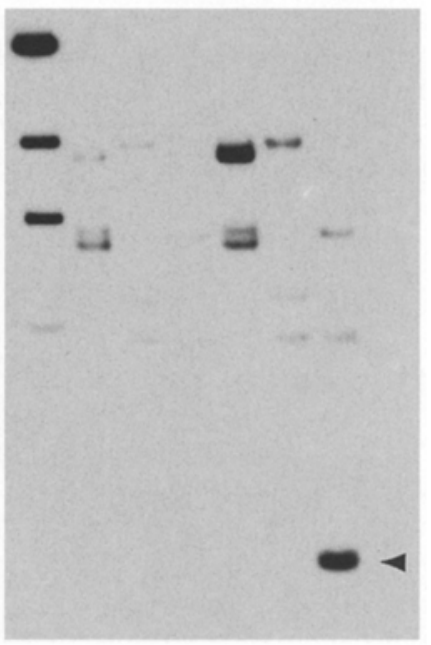

Fig. 2 a,b Southern-blot hybridization showing control and 5-ACtreated triticale rDNA restriction patterns. Untreated plant (lanes 1-3); 5-AC-treated (lanes 4-6); ApaI digest (lanes 1, 4); DraI (lanes 2, 5); Apal/DraI (lanes 3, 6). $M$ bacteriophage lambda digested with HindIII, bands at $23,9,7$, and $4 \mathrm{~kb}$. a Probed with the wheat rDNA repeat unit (pTa71); b reprobed with the rye intergenic spacer (pScR4.T1). An extra restriction fragment, $1.9 \mathrm{~kb}$ (arrowed), largely of rye origin, is present only in the 5-AC treatment, where the NOR of rye origin is active

Silver staining of root-tip cells shows that germination of triticale seeds in 5-AC activates rRNA genes of rye origin which are normally inactive (Fig. 1). Southern hybridization indicates that the effect correlates with a reduction in the methylation of a cytosine residue in the intergenic spacer (Fig. 2), and is presumably mediated through this, or other, methylated sites. Rye and wheat rDNA repeat units have a DraI polymorphism (HeslopHarrison et al. 1990), and $A p a I$ activity is inhibited by 5-methylcytosine at either underlined $\mathrm{C}$ in the recognition sequence GGGCCC. Figure 4 shows restriction maps of the wheat $6 \mathrm{~B}$ and rye $1 \mathrm{R}$ rDNA repeat units. In Fig. 2, there is one major rDNA fragment visible only in lane b6, showing that the 5-AC treatment reduces methylation of rDNA (because the fragment is absent in lane $\mathrm{b} 3$ and hence 5-AC treatment facilitates ApaI digestion), and the novel rDNA fragment is of rye origin (Figs. 2, 4).

Comparison of the wheat (Barker et al. 1988) and rye (Appels et al. 1986) intergenic spacer and the subtending 25s sequence shows that both have an $A p a I$ site about $2.1 \mathrm{~kb}$ from the $5^{\prime}$ DraI site while rye alone has a $\mathrm{DraI}$ site in the $18 \mathrm{~s}-25 \mathrm{~s}$ intergenic spacer (Fig. 4). It is evident that two rye $A p a \mathrm{I}$ recognition sites are methylated in the untreated triticales, but 5-AC treatment prevents their methylation, resulting in fragments including the $1.9-\mathrm{kb}$ ApaI-DraI fragment strongly revealed in Fig. 2b, lane 6 (Fig. 4 c). Therefore, external application of 5-AC causes a reduction of methylation at defined sites in a gene unit. Such methylation reduction within the gene unit itself is likely to lead to its expression.

In normal wheat and rye plants, rRNA genes are active at least up to late gametogenesis, but in the wheat $\times$ rye $F_{1}$ hybrids the rye genes are inactive in the seedling and adult plant. Our results show that the inactivation is established early in embryogenesis, but is
Fig. 3a-c Wheat $\times$ rye $F_{1}$ hybrid metaphases from treatment 3 (a) treatment 6 (b) treatment 9 (c) after silver staining (arrows). Two subterminal, silver-stained wheat-origin NORs are visible in all treatments. Rye-origin subterminal subterminal NORs are strongly silver stained in treatment 9 , while they are unstained or only weakly stained (b, open arrow) in all other treatments, indicating that the rRNA genes of rye origin are inactive

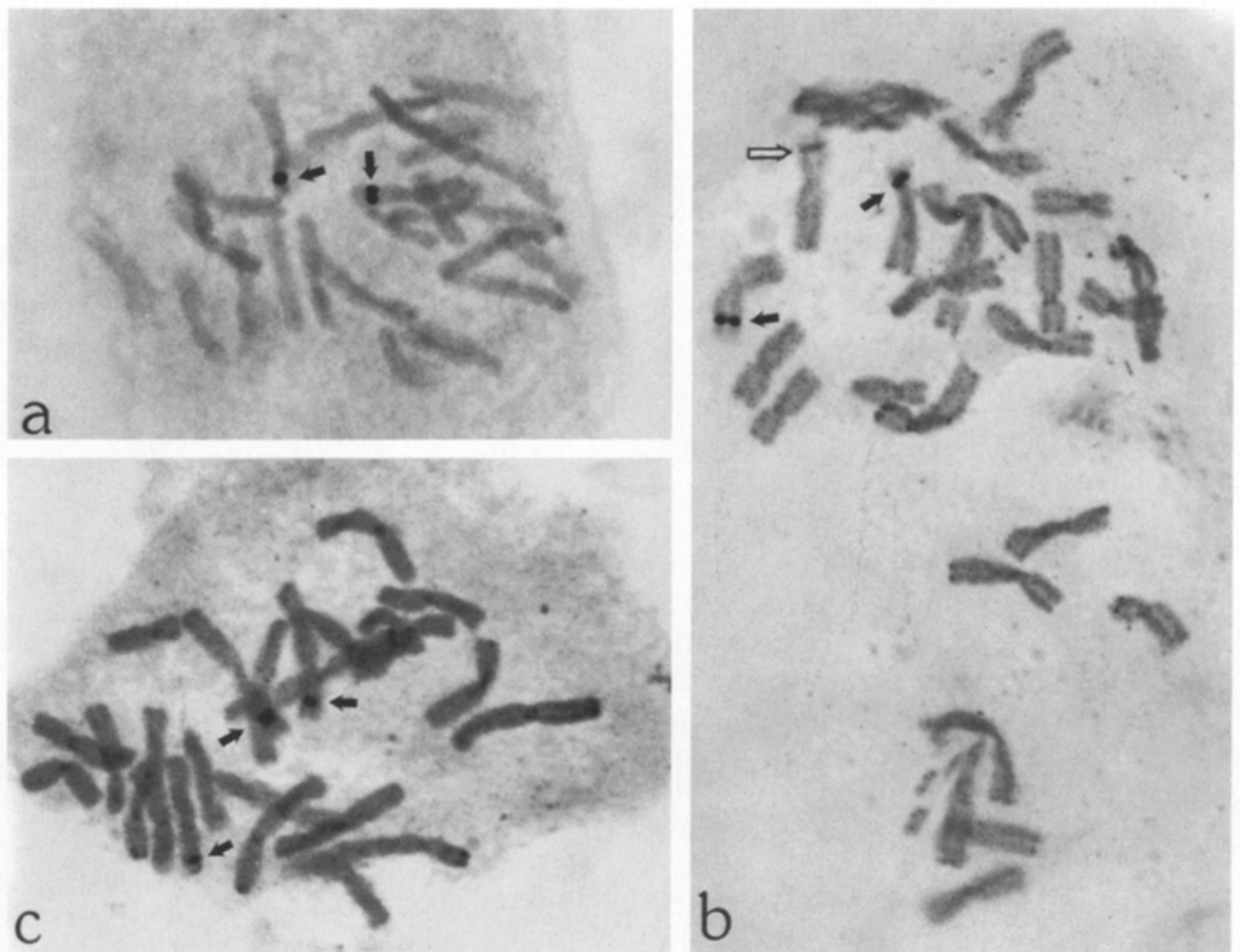


Table 1 The frequency of metaphases with different numbers of silver-stained subterminal NORs in root-tips of (a) wheat $\times$ rye $F_{1}$ hybrids and (b) triticale cv Juanilho from untreated embryos, or embryos treated with 5 -AC 3,6 and 9 days after pollination. In triticale, chi-square contingency tests showed that untreated embryos and treatments 3 and 6 were not significantly different $(0.5>P>0.25)$, but treatment 9 was very high significantly different $(P<0.001)$ from the others

\begin{tabular}{|c|c|c|c|c|c|c|c|}
\hline \multirow[t]{2}{*}{ Material } & \multirow[t]{2}{*}{ Treatment } & \multirow[t]{2}{*}{$\begin{array}{l}\text { No. of scored } \\
\text { metaphase cells }\end{array}$} & \multicolumn{5}{|c|}{$\begin{array}{l}\text { Frequencies of metaphases with different number of } \\
\text { Ag-SAT-NORs }\end{array}$} \\
\hline & & & 2 & 3 & 4 & 5 & 6 \\
\hline $\begin{array}{l}\text { Wheat } \times \text { rye } \\
\mathrm{F}_{1} \text { hybrid }\end{array}$ & $\begin{array}{l}\text { Control } \\
3 \\
6 \\
9\end{array}$ & $\begin{array}{l}33 \\
51 \\
87 \\
73\end{array}$ & $\begin{array}{l}100 \\
100 \\
100 \\
19.18\end{array}$ & $\begin{array}{c}0 \\
0 \\
0 \\
80.82\end{array}$ & $\begin{array}{l}- \\
- \\
- \\
-\end{array}$ & $\begin{array}{l}- \\
- \\
- \\
-\end{array}$ & $\begin{array}{l}- \\
- \\
- \\
-\end{array}$ \\
\hline $\begin{array}{l}\text { 6x Triticale } \\
\text { cv Juanilho }\end{array}$ & $\begin{array}{l}\text { Control } \\
3 \\
6 \\
9\end{array}$ & $\begin{array}{r}165 \\
123 \\
81 \\
95\end{array}$ & $\begin{array}{l}1.82 \\
0 \\
0 \\
0\end{array}$ & $\begin{array}{l}8.49 \\
8.95 \\
8.64 \\
5.26\end{array}$ & $\begin{array}{l}86.06 \\
86.99 \\
87.65 \\
15.79\end{array}$ & $\begin{array}{r}2.42 \\
3.25 \\
2.47 \\
31.58\end{array}$ & $\begin{array}{r}1.21 \\
0.81 \\
1.24 \\
47.37\end{array}$ \\
\hline
\end{tabular}

a. Wheat

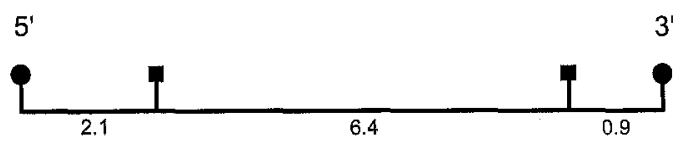

b.

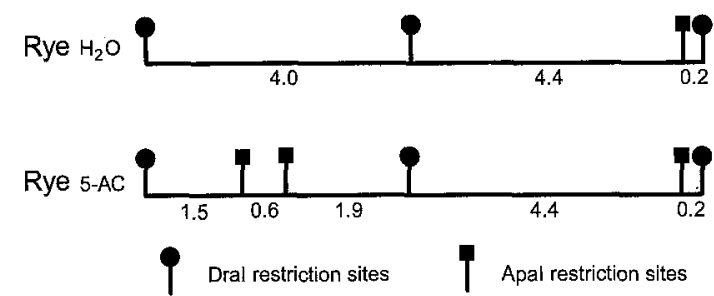

Fig. 4a-c Maps of the rDNA repeat unit showing DraI and ApaI restriction sites in wheat and rye (based on sequences in the EMBL/Genbank database). a Constant restriction fragments originating from wheat chromosome $6 \mathrm{~B}$ are visible in all lanes (Fig. 2; the 1B NOR has some minor variants). b From rye-origin sequence, only one Apal site is cut in the DNA from the control plants, giving a single rye-origin $A p a I$ restriction fragment (Fig. 2, lanes 1) and no limitingmobility DNA. c After 5-AC treatment, two further ApaI sites become accessible in the rye-origin rDNA unit. Additional fragments are seen in the ApaI/DraI double digests, of which the $1.9-\mathrm{kb}$ fragment is strongly detected (Fig. 2, lanes 6), correlating with activation of the rye-origin NORs detected by silver staining (Fig. 1)

reversible by 5 -AC treatment at a later stage (Fig. 3, Table 1). Hence there is an important change during embryo development. Before 7 days post-fertilization, modifications of the rDNA methylation patterns with 5-AC are not maintained as no effect on rRNA gene expression is detected in the resulting seedling. These data imply that de novo methylases (or associated, perhaps, sequence-specific, DNA-binding proteins) are active and establish the methylation imprint on the ryeorigin rRNA genes. Later, the methylation imprint can be irreversibly erased by 5-AC treatment. Hence we suggest that de novo methylases are active until the 7th day after fertilization when the imprinting is completed and the activity of maintenance methylases then keeps the rye-origin rDNA methylation pattern largely constant.

Acknowledgements We thank Mrs. Augusta Barao and Gill Harrison for assistance. Nuno Neves is grateful to the Portuguese JNICT (BD/1605) for financial support.

\section{References}

Anamthawat-Jónsson K, Schwarzacher T, Leitch AR, Bennett MD, Heslop-Harrison JS (1990) Discrimination between closely related Triticeae species using genomic DNA as a probe. Theor Appl Genet 79:721-718

Appels R, Moran LB, Gustafson JP (1986) The structure of DNA from the rye (Secale cereale) NOR R1 locus and its behaviour in wheat backgrounds. Can J Genet Cytol 28:673-685

Barker RF, Harberd NP, Jarvis MG, Flavell RB (1988) Structure and evolution of the intergenic region in a ribosomal DNA repeat unit of wheat. J Mol Biol 201:1-17

Barlow DP (1993) Methylation and imprinting - from host defence to gene regulation. Science 260:309-310

Ferguson-Smith AC, Sasaki H, Cattanach BM, Surani MA (1993) Parental origin-specific epigenetic modification of the mouse H19 gene. Nature $362: 751-755$

Gerlach WL, Bedbrook JR (1979) Cloning and characterization of ribosomal RNA genes from wheat and barley. Nucleic Acids Res $7: 1869-1885$

Hayashibara KC, Verdine GL (1992) Template-directed interference footprinting of cytosine contacts in a protein-DNA complex: potent interference by 5-aza-2'deoxycytidine. Biochemistry 31:11265-11273

Heslop-Harrison JS (1990) Gene expression and parental dominance in hybrid plants. Development 1105:21-28

Heslop-Harrison JS, Leitch AR, Schwarzacher T, Anamthawat-Jónsson K (1990) Detection and characterization of $1 B / 1 R$ translocations in hexaploid wheat. Heredity $65: 285-294$

Hubbell HR (1985) Silver staining as an indicator of active ribosomal genes. Stain Technol 60:285-294

Jimenez M, Jimenez R, Burgos M, Diaz de la Espina R (1988) A study of the Ag-staining significance in mitotic NORs. Heredity $60: 125-127$

Jones PA (1985) Altering gene expression with 5-azacytidine. Cell 40:485-486

Lacadena JR, Cermeño MC, Orellana J (1984) Evidence for wheatrye nucleolar competition (amphiplasty) in triticale by the silverstaining procedure. Theor Appl Genet 67:207-213 
Lacadena JR, Cermeno MC, Orellana J, Santos JL (1988) Nucleolar competition in Triticeae. Kew Chrom Conf III: 151-165

Navashin M (1934) Chromosomal alterations caused by hybridization and their bearing upon certain general genetic problems. Cytologia 5:169-203

Ottaviani M-P, Smits T, Hänische ten Cate C (1993) Differential methylation and expression of the beta-glucuronidase and neomysin phosphotransferase genes in transgenic plants of potato cv Bintje. Plant Sci 88:73-81
Reeder H (1985) Mechanisms of nucelolar dominance in animals and plants. J Cell Biol 101:2013-2016

Sardana R, O'Dell M, Flavell RB (1993) Correlation between the size of the intergenic regulatory region, the status of cytosine methylation of rRNA genes and nucleolar expression in wheat. Mol Gen Genet 236:155-162

Vieira R, Queiroz A, Morais L, Barao A, Mello-Sampayo T, Viegas WS (1990) 1R chromosome nucleolus organizer region activation by 5 -azacytidine in wheat $\times$ rye hybrids. Genome $33: 707-712$ 